\title{
Spatial-Temporal Change of Land Use and Its Impact on Water Quality of East-Liao River Basin from 2000 to 2020
}

\author{
Mingxi Zhang ${ }^{1,2,3}$, Guangzhi Rong ${ }^{1,2,3}$, Aru Han ${ }^{1,2,3}$, Dao Riao ${ }^{1,2,3}$, Xingpeng Liu ${ }^{1,2,3, *}$, Jiquan Zhang ${ }^{1,2,3}$ and \\ Zhijun Tong ${ }^{1,2,3}$ \\ 1 School of Environment, Northeast Normal University, Changchun 130024, China; \\ zhangyq017@nenu.edu.cn (M.Z.); ronggz728@nenu.edu.cn (G.R.); arh690@nenu.edu.cn (A.H.); \\ daora388@nenu.edu.cn (D.R.); zhangjq022@nenu.edu.cn (J.Z.); gis@nenu.edu.cn (Z.T.) \\ 2 Department of Environment, Institute of Natural Disaster Research Northeast Normal University, \\ Changchun 130024, China \\ 3 Key Laboratory for Vegetation Ecology, Ministry of Education, Changchun 130024, China \\ * Correspondence: liuxp912@nenu.edu.cn; Tel.: +86-139-4406-7540
}

Citation: Zhang, M.; Rong, G.; Han, A.; Riao, D.; Liu, X.; Zhang, J.; Tong, Z. Spatial-Temporal Change of Land Use and Its Impact on Water Quality of East-Liao River Basin from 2000 to 2020. Water 2021, 13, 1955. https:// doi.org/10.3390/w13141955

Academic Editors: Roko Andricevic and David Post

Received: 13 May 2021

Accepted: 14 July 2021

Published: 16 July 2021

Publisher's Note: MDPI stays neutral with regard to jurisdictional claims in published maps and institutional affiliations.

Copyright: () 2021 by the authors. Licensee MDPI, Basel, Switzerland. This article is an open access article distributed under the terms and conditions of the Creative Commons Attribution (CC BY) license (https:// creativecommons.org/licenses/by/ $4.0 /)$.

\begin{abstract}
Land use change is an important driving force factor affecting the river water environment and directly affecting water quality. To analyze the impact of land use change on water quality change, this study first analyzed the land use change index of the study area. Then, the study area was divided into three subzones based on surface runoff. The relationship between the characteristics of land use change and the water quality grade was obtained by grey correlation analysis. The results showed that the land use types changed significantly in the study area since 2000, and water body and forest land were the two land types with the most significant changes. The transfer rate is cultivated field $>$ forest land $>$ construction land $>$ grassland $>$ unused land $>$ water body. The entropy value of land use information is represented as Area I $>$ Area III $>$ Area II. The shift range of gravity center is forest land $>$ grassland $>$ water body $>$ unused land $>$ construction land $>$ cultivated field. There is a strong correlation between land use change index and water quality, which can be improved and managed by changing the land use type. It is necessary to establish ecological protection areas or functional areas in Area I, artificial lawns or plantations shall be built in the river around the water body to intercept pollutants from non-point source pollution in Area II, and scientific and rational farming in the lower reaches of rivers can reduce non-point source pollution caused by farming.
\end{abstract}

Keywords: land use change; transfer matrix; water quality; grey correlation degree

\section{Introduction}

Land use is a dynamic process that refers to the way and purpose of humans' use of the natural attributes of land [1], and land use change is a dominant process with negative effects on the structure and functioning of the surface ecological environment system [2-4]. Land use is also an essential driving forces factor that affects rivers' hydrological changes [5-7] and causes changes in surface runoff [8-10]. In the past, the forest and grassland on both sides of the river have become a large number of sloping farmlands in China, and this kind of human activity leads to deterioration of the river water environment [11-13], then it causes the large-area non-point source pollution and ultimately affects the river water quality in the basin. Therefore, the analysis of the relationship between land use change and water environment can provide scientific decision support for watershed water environment management in terms of land structure and land use patterns.

Due to the importance of land use in the surface environment, land use has become a hot issue in numerous studies. Several studies have conducted extensive research on different watersheds' land use dynamics and spatial patterns at different scales and periods in the past decade [1-13]. Most studies focused on the spatio-temporal characteristics of 
land use change and its driving mechanism [14-16] and their impact on climate [17-19]. In the impact of land use change on the watershed water environment, studies were limited to reflect the linear relationship between land use and water quality [20-22] and the impact of land use change on the pollution level of river basins [23-25]. The impact of land use change on the water environment is complex. The single land use change index cannot truly represent the change characteristics of water quality. Few studies have analyzed the impact of the multiple land use change index on the water environment.

Since the water quality is closely related to the surface runoff, this study divided the study area into three subzones according to the surface runoff. The multiple index, including land use transfer matrix, land use importance index, land use information humidity, and land use gravity center transfer model, the land use characteristics, and spatial distribution pattern of the East-Liao River Basin, was comprehensively analyzed in Jilin Province from 2000 to 2020. The relationship between the land use change index and the water quality change of the water quality monitoring points at the outlet of the three subzones was established in the study area. The purposes of this study are to reveal the spatial and temporal distribution characteristics of land use in the East-Liao River Basin, analyze the water quality change characteristics in the East-Liao River Basin, and establish the relationship between land use change and water quality by using the grey correlation method. It will provide a basis for decision-making on water resources management in the East-Liao River Basin. It could also provide a reference for land use planning and runoff management in other river basins. The results will also promote the planning and management of watershed water resources and sustainable land use [26-28].

\section{Materials and Methods}

\subsection{Study Area}

The East-Liao River is located in the Midwest Jilin Province $\left(42^{\circ} 53^{\prime}-43^{\circ} 25^{\prime} \mathrm{N}, 123^{\circ} 43^{\prime}-\right.$ $125^{\circ} 08^{\prime}$ E) (Figure 1). It is one of the main farming areas in Jilin Province and covers $13,196 \mathrm{~km}^{2}$, including three cities (Siping, Liaoyuan, and Gongzhuling). The terrain is flat and broad, and the altitude drops from 130 to $107 \mathrm{~m}$. The study area belongs to the temperate monsoon climate zone, with an annual mean temperature of $5.2{ }^{\circ} \mathrm{C}$. Soil types include black soil, dark brown forest soil, and brown soil. The mean annual runoff is $7.5 \times 10^{8} \mathrm{~m}^{3}$, which varies significantly with seasons and can be divided into winter dry season, spring flood season (snowmelt period), spring-summer turn-off period, and summer flood season. Total water supply was 19.06 billion $\mathrm{m}^{3}$, and water consumption for living, agriculture, and industry were 31.1 million $\mathrm{m}^{3}, 129.7$ million $\mathrm{m}^{3}$, and 3.38 billion $\mathrm{m}^{3}$, respectively. Land use types mainly include cultivated fields, construction land, forest land, grassland, water bodies, and unused land (Figure 2). Non-point source pollution is an important factor affecting local water quality, and $\mathrm{TP}, \mathrm{NH}_{3}-\mathrm{N}$, and $I_{\mathrm{Mn}}$ are the primary pollutants $[29,30]$. The study area has been seriously affected by water pollution in the past decades. Therefore, adjusting land use has become a meaningful way to solve local water pollution problems. Previous studies have found that the main environmental problems in this area are non-point source pollution [31], therefore, we assume that water quality change is closely related to land use change. The three subzones are divided according to the direction of the river inflow. Since the pollutants in the water body are inherited, Area I is set to the river's source, Area II is set to the middle part of the river and includes Area I, and Area III is set to the downstream of the study area and includes Areas I and II. 

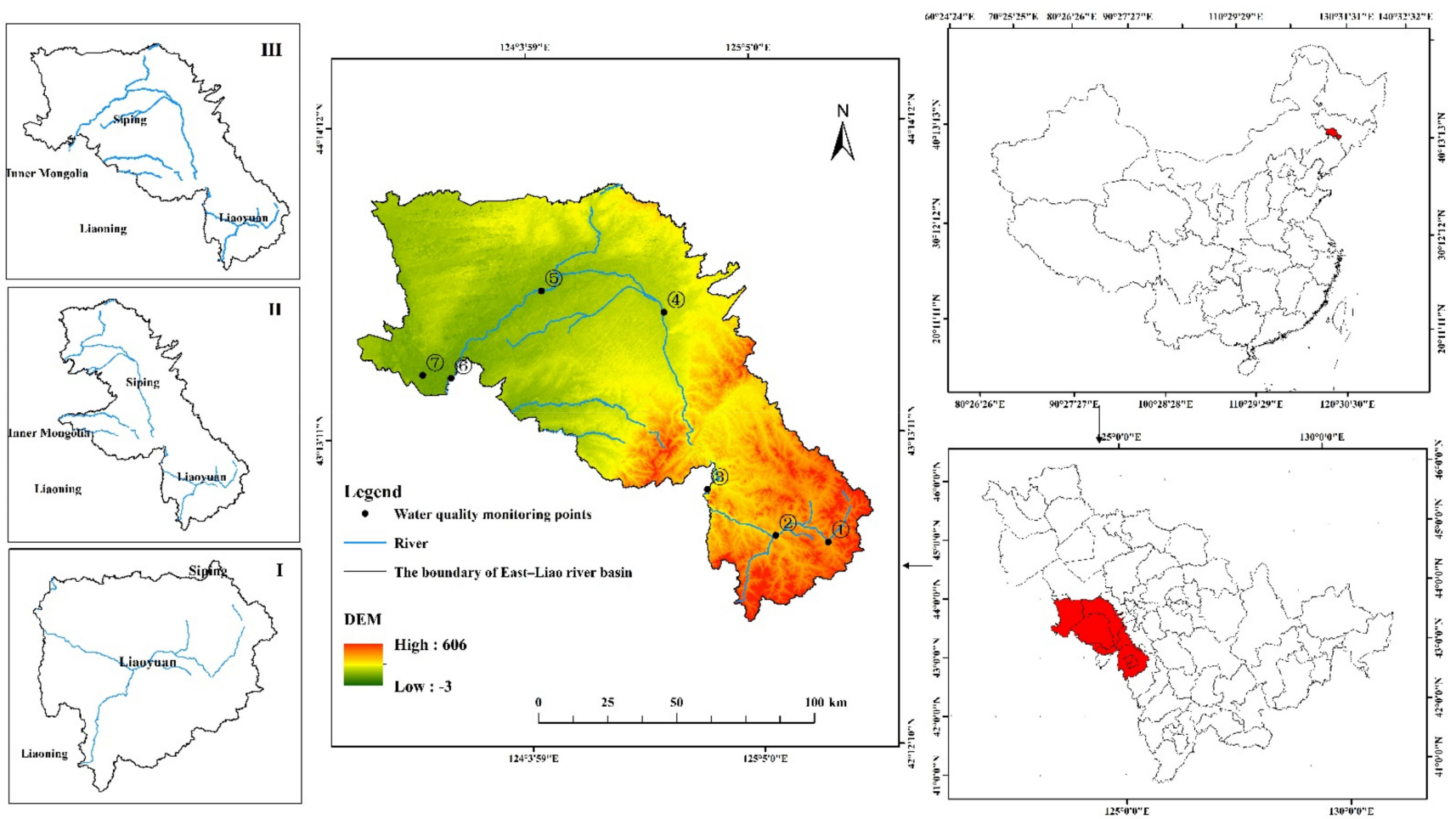

Figure 1. The study area and monitoring points.

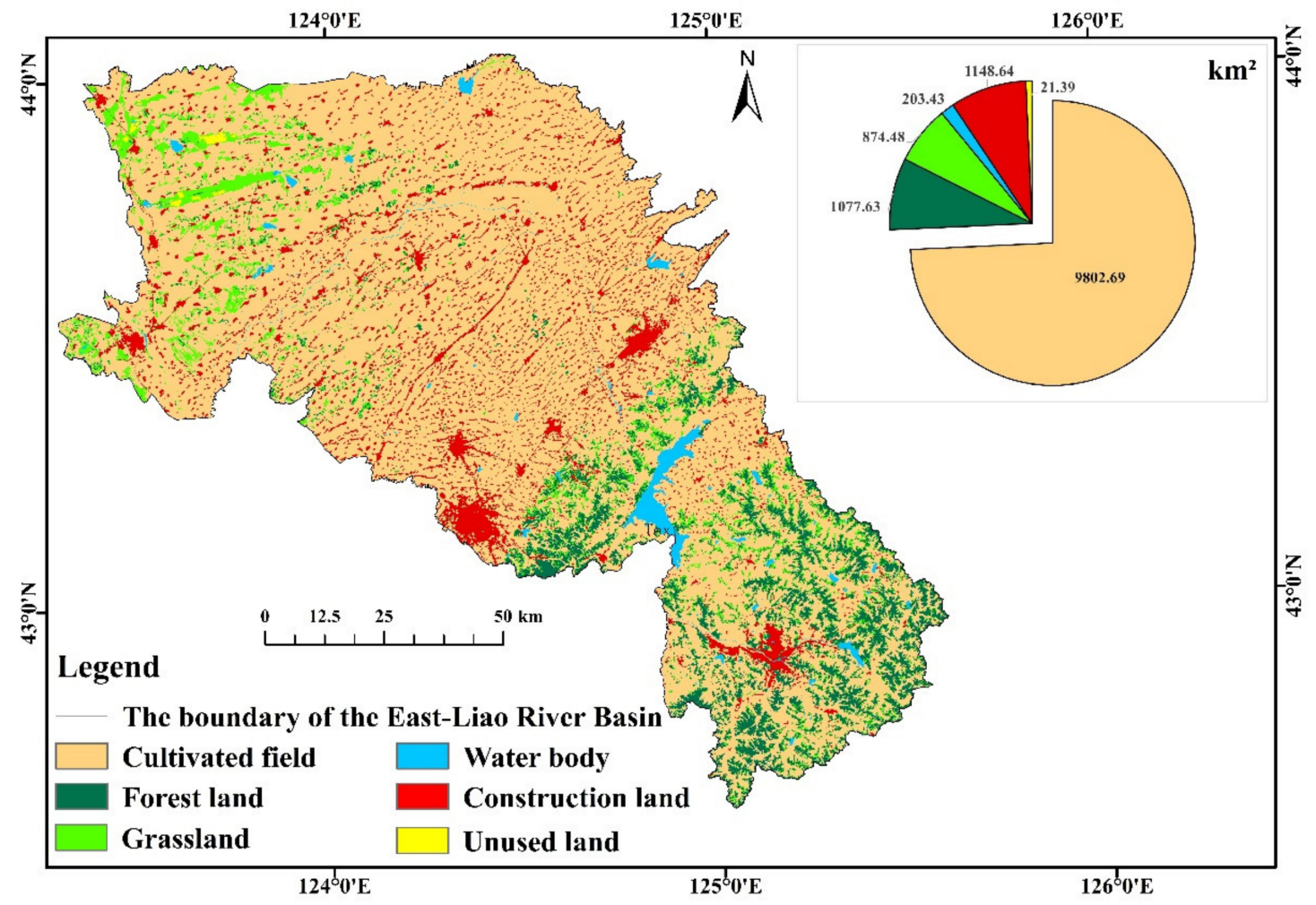

Figure 2. Spatial distribution and area of land use types in the East-Liao river basin in 2020.

\subsection{Data Sources}

The data of land use types, water quality, and Digital Elevation Model (DEM) are mainly used in this study. The land use data (2000-2020) with $30 \mathrm{~m}$ spatial resolution 
were collected from the Resource and Environmental Science Data Center of the Chinese Academy of Sciences [32]. According to the three-level classification system of land use and land cover data in China, the land use is divided into six categories: cultivated field, forest land, grassland, water body, construction land, and unused land. The random field investigation was conducted on the land use type data provided by the Resource and Environmental Science Data Center of the Chinese Academy of Sciences to verify the reliability of the data. The water quality grade was obtained from monitoring data. The DEM was obtained from the geospatial data cloud [33].

\subsection{Methods}

The multiple land use change index was used to analyze land use change characteristics in the regional water environment of the study area. Then, the difference between land use change index and water quality grade change was initially established. The methods of the land use change index used in this study are shown in Table 1.

Table 1. Calculation equations and their description.

\begin{tabular}{|c|c|c|c|c|}
\hline Methods & Equation & & Description & Reference \\
\hline $\begin{array}{l}\text { Land use transfer } \\
\text { matrix }\end{array}$ & $\begin{array}{c}X_{t}=\frac{\sum_{i=1}^{m}\left(C_{t i} X_{i}\right)}{\sum_{i=1}^{m} C_{t i}} \\
Y_{t}=\frac{\sum_{i=1}^{m}\left(C_{t i} Y_{i}\right)}{\sum_{i=1}^{m} C_{t i}} \\
D_{t^{\prime}-t}=C \times \sqrt{\left(Y_{t^{\prime}}-Y_{t}\right)^{2}+\left(X_{t^{\prime}}-X_{t}\right)^{2}}\end{array}$ & (4) & $\begin{array}{l}\text { where } S \text { is the area of land use type, } n \\
\text { is the land use type, and } S_{i j} \text { indicates } \\
\text { the area of class } i \text { land converted to } \\
\text { level } j \text { land at the beginning of the } \\
\text { study period. Besides, the sum of } \\
\text { each row of the transfer matrix } \\
\text { represents the total area of land use } \\
\text { type } i \text { at the beginning of the study, } \\
\text { and each row value represents the } \\
\text { transfer destination and size of the } \\
\text { land type. The sum of class } i \text { indicates } \\
\text { the total area of the land type at the } \\
\text { end of the study, and each row of } \\
\text { values shows all the incoming types } \\
\text { and sizes of the land type } \\
\text { where } X_{t} \text { and } Y_{t} \text { are the longitude } \\
\text { and latitude coordinates of the center } \\
\text { of gravity of the distribution of type } i \\
\text { land resources in the year } t, C_{t i} \text { is the } \\
\text { area of this kind of land resources in } \\
\text { the } i \text { region in the year } t, X_{i} \text { and } Y_{i} \text { are } \\
\text { the longitude and latitude of the i-th } \\
\text { land resource patch, and m is the total } \\
\text { number of land resource patches. } \\
\text { where } D \text { is the distance of gravity } \\
\text { center migration between two } \\
\text { different years, and } t^{\prime} \text { and } t \text { are two } \\
\text { other years. }\left(X_{t^{\prime}}, Y_{t^{\prime}} \text { ) and ( } X_{t}, Y_{t} \text { ) are }\right. \\
\text { the geographical coordinates } \\
\text { (longitude and latitude) of the space } \\
\text { where the regional center of gravity is } \\
\text { located in the } t^{\prime} \text { and } t \text { years, } \\
\text { respectively. } C=111.111 \text { is a constant, } \\
\text { which is a coefficient that converts } \\
\text { geographical coordinate units } \\
\text { (longitude and latitude) into the } \\
\text { plane distance (km). }\end{array}$ & {$[35,36]$} \\
\hline
\end{tabular}


Table 1. Cont.

\begin{tabular}{|c|c|c|c|c|}
\hline Methods & Equation & & Description & Reference \\
\hline $\begin{array}{l}\text { Land use, the } \\
\text { dynamic degree }\end{array}$ & $K=\frac{U_{b}-U_{a}}{U_{a}} \times \frac{1}{T} \times 100 \%$ & (5) & $\begin{array}{l}\text { where } U_{a} \text { and } \mathrm{U}_{\mathrm{b}} \text { are the numbers of a } \\
\text { certain land use type at the beginning } \\
\text { and the end of the study. } T \text { is the } \\
\text { study period. When } t \text { is the year, } K \\
\text { value is the annual change rate of a } \\
\text { certain land use type in the study } \\
\text { area. }\end{array}$ & [37] \\
\hline $\begin{array}{l}\text { Land use change } \\
\text { important index }\end{array}$ & $C_{i}=\frac{A_{i}}{\sum_{i=1}^{n} A_{i}} \times 100 \%$ & (6) & $\begin{array}{l}\text { where } C_{i} \text { is the land use importance } \\
\text { index of the } i \text {-th change type, with a } \\
\text { value of } 0-100(\%), A_{i} \text { is the land } \\
\text { change area of type } i\left(\mathrm{~km}^{2}\right) \text {, and } A \text { is } \\
\text { the sum of various land change areas } \\
\text { in the region }\left(\mathrm{km}^{2}\right) .\end{array}$ & [38] \\
\hline $\begin{array}{l}\text { The information } \\
\text { entropy of land use } \\
\text { structure }\end{array}$ & $H=-\sum_{i=1}^{n} P_{i} \times \ln P_{i}$ & (7) & $\begin{array}{l}\text { where } P_{i} \text { is the proportion of land use } \\
\text { type } i \text {, and } n \text { is the number of land } \\
\text { use types. The larger the } H \text { value is, } \\
\text { the more complex the land use types } \\
\text { and their internal relations are. }\end{array}$ & [39] \\
\hline
\end{tabular}

In this study, grey correlation degree is used to analyze the fuzzy relationship between land use change index and water quality grade. The principle and method of grey system theory are applied $[40,41]$. The impact of the land use change index on water quality is analyzed, and the related ranking is calculated in different subzones. The comparison sequence is set as $A(i, j)(i=1,2, \ldots, 12)$, which represents the $j$-th index in the $i$-th land use change index. $A(0, j)$ is an ideal sequence composed of the maximum value of the physical and chemical properties. The linear standardization method is used for dimensionless processing: $A(i, j) / A(0, j)$.

The calculation equation of the correlation coefficient is as follows:

$$
r(i, j)=\frac{\min _{i} \min _{j}|A(0, j)-A(i, j)|+\xi \times \max _{i} \max _{j}|A(0, j)-A(i, j)|}{|A(0, j)-A(i, j)|+\xi \times \max _{i} \max _{j}|A(0, j)-A(i, j)|},
$$

The formula for calculating the degree of association is as follows:

$$
R(i, j)=\sum_{j=1}^{n} r(i, j) \omega_{i j}
$$

where $\xi$ is the resolution coefficient, with a value of $0.5, n=12$, and $\omega_{i j}$ is the weight of the $j$-th index in the $i$-th land use change index.

The correlation threshold $R o$ and $R(i, j)$ are compared to verify the reliability of the model. $R(i, j)>$ Ro means that the model is credible. A higher value of $R(i, j)$ means higher credibility of the model [42].

The study was first divided into three areas (I, II, and III) to study the spatio-temporal change of land use and its impact on the water environment. Secondly, the water quality monitoring points in the East-Liao River Basin were counted. The changes in water quality were analyzed in the East-Liao River Basin from 2000 to 2020. Thirdly, the grey correlation model was used to analyze the water quality and land use change index. Finally, the grey correlation degree and ranking of the land use change index affecting water quality were obtained. 


\section{Results}

\subsection{Temporal-Spatial Variation of Land Use}

\subsubsection{Temporal Variation of Land Use}

According to the annual land use data, the land use area change map was calculated and is shown in Figure 3 and Table 2. It shows that cultivated fields and grassland have a trend of decreasing first and then increasing. The area change trend of forest land and unused land shows increasing first and then decreasing. The water body has been shrinking, while the construction land area has remained stable since 2000.

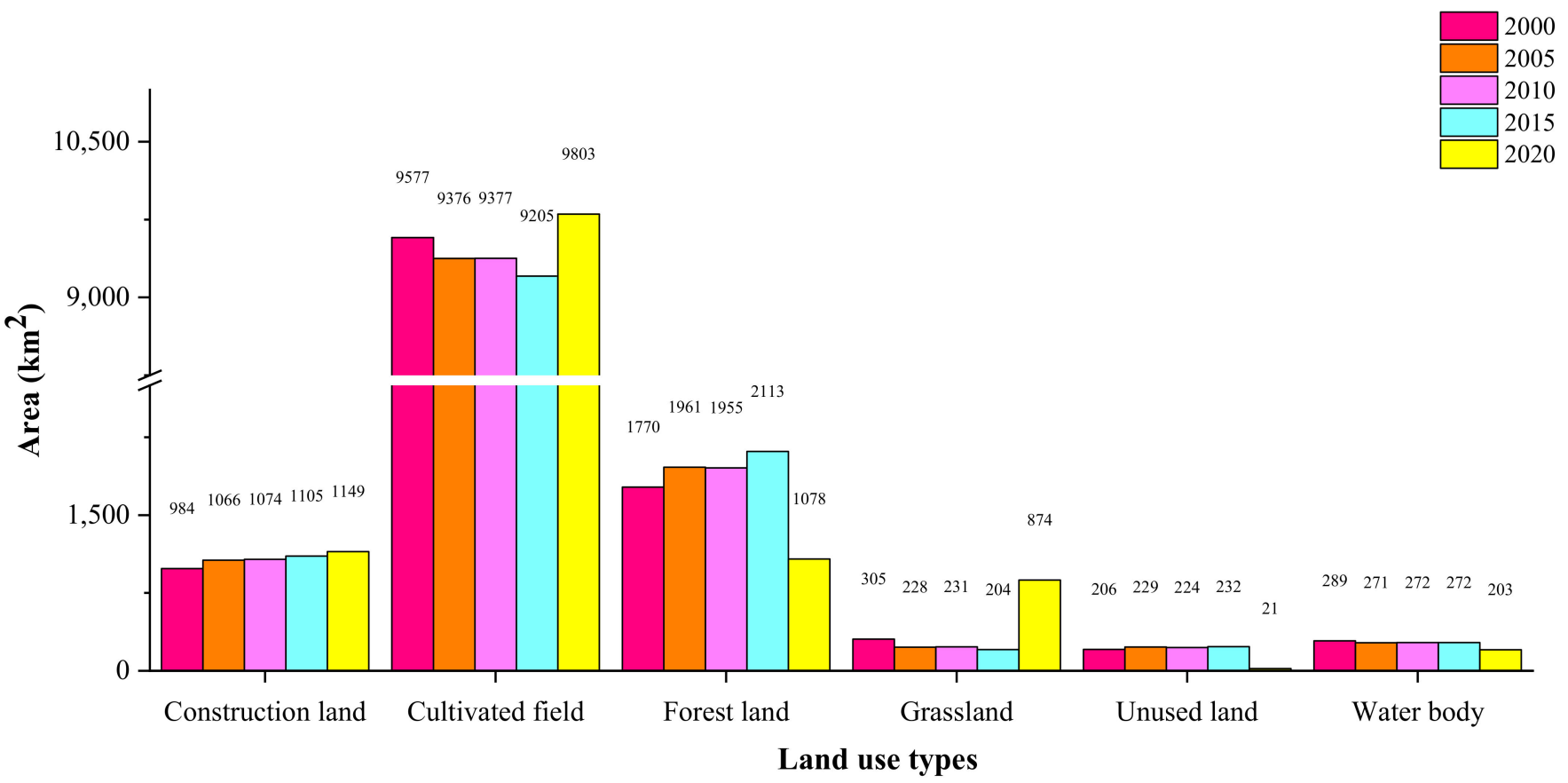

Figure 3. Time series of area changes in land use types from 2000 to $2020\left(\mathrm{~km}^{2}\right)$.

Table 2. Time series of area change values of land use types from 2000 to $2020\left(\mathrm{~km}^{2}\right)$.

\begin{tabular}{cccccc}
\hline & Area & \multicolumn{5}{c}{ Years } \\
\cline { 2 - 6 } Types & $\mathbf{2 0 0 0}$ & $\mathbf{2 0 0 5}$ & $\mathbf{2 0 1 0}$ & $\mathbf{2 0 1 5}$ & $\mathbf{2 0 2 0}$ \\
\hline Cultivated field & 9577.11 & 9375.74 & 9376.71 & 9205.45 & 9802.69 \\
Forest land & 1769.97 & 1961.44 & 1954.54 & 2113.10 & 1077.63 \\
Grassland & 304.56 & 227.62 & 231.41 & 204.38 & 874.48 \\
Water body & 289.11 & 271.09 & 272.28 & 272.37 & 203.43 \\
Construction land & 984.08 & 1066.25 & 1073.61 & 1105.41 & 1148.64 \\
Unused land & 205.93 & 228.98 & 224.15 & 231.94 & 21.39 \\
\hline
\end{tabular}

\subsubsection{Spatial Variation of Land Use}

It can be seen from the spatial distribution of land use (Figure 4) that cultivated field is the primary type of land use in the basin. Forest land is mainly distributed in the southeast of the basin. By calculating each land use type area, it was found that the cultivated field, grassland, and construction land increased by $2.36 \%, 187.13 \%$, and $16.72 \%$, respectively. The areas of forest land, water bodies, and unused land decreased by $39.12 \%, 29.64 \%$, and $89.61 \%$. The grassland area decreased from 2000 to 2015, but it increased rapidly from 2015 to 2020 , with an increased rate of $327.88 \%$. 

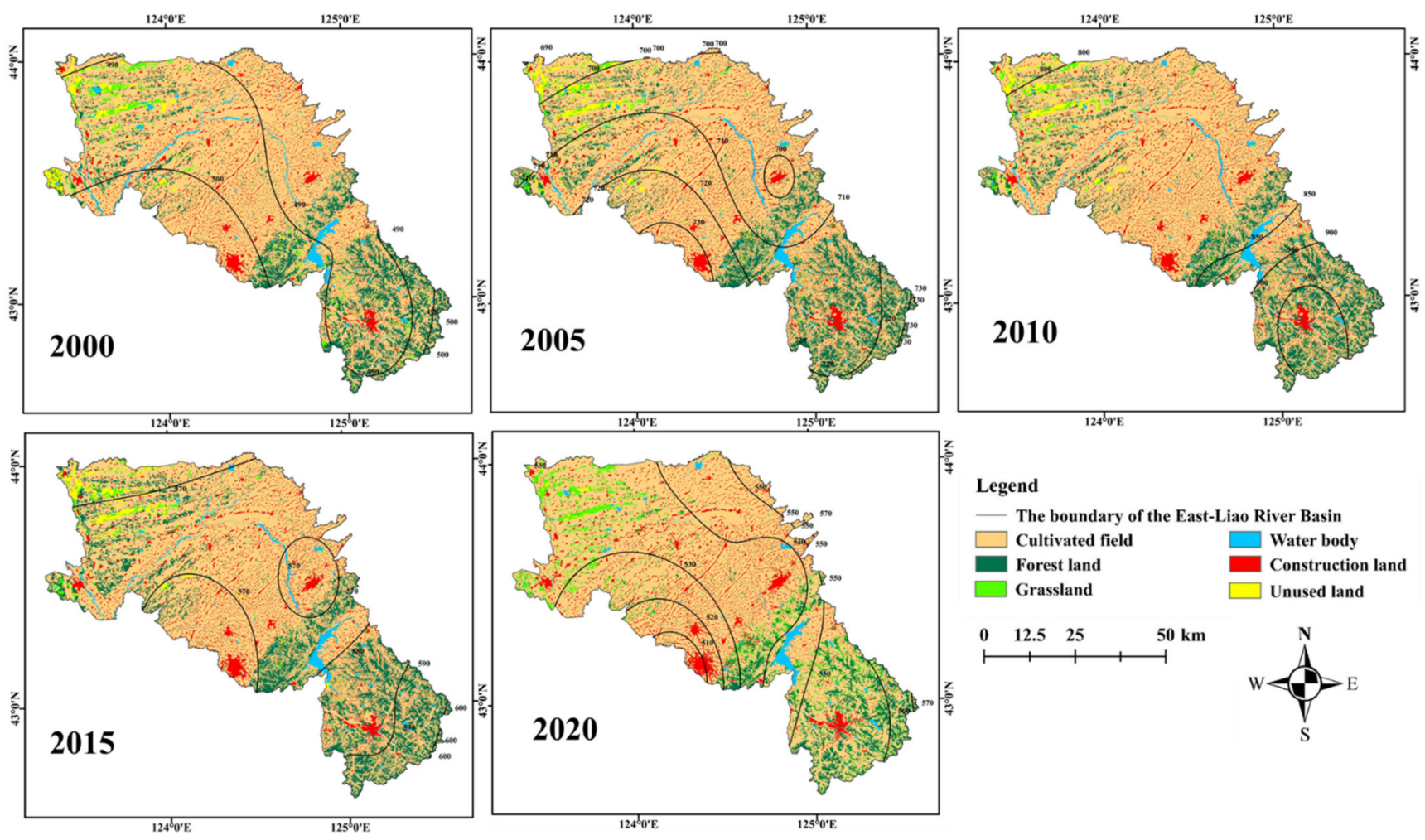

Figure 4. Spatial variation of land use types $\left(\mathrm{km}^{2}\right)$ and annual mean rainfall isoline (mm) from 2000 to 2020.

The land use transfer matrix could quantitatively and intuitively reflect land use types and areas in the two different periods. As shown in Figure 5, the more grid points in the map, the larger the area transferred to other land use types. Part of the area has been changed from cultivated field to forest land, construction land, grassland, water body, and unused land, with a transfer area of $1032.09 \mathrm{~km}^{2}$. The land use types transferred from forest land include cultivated fields, grassland, and water body, with a transfer area of $929.84 \mathrm{~km}^{2}$. The transfer areas of grassland, water body, construction land, and unused land are $193.80,135.03,377.89$, and $193.09 \mathrm{~km}^{2}$. All land use types were mainly transferred to the cultivated fields.

The center of gravity model is a critical analysis tool to describe land use types' temporal and spatial evolution. The change of gravity center of land use type is shown in Figure 6 . The migration range of grassland is within $30 \mathrm{~km}$. The migration scope of the cultivated fields is relatively small, and the farthest migration distance is only $1 \mathrm{~km}$. The overall migration direction of construction land is northwest, with the farthest migration distance of $9 \mathrm{~km}$. The whole migration direction of unused land is northwest, and the migration distance is $14 \mathrm{~km}$. Forest land and water body migrated to the southeast, with migration distances of 24 and $31 \mathrm{~km}$. 

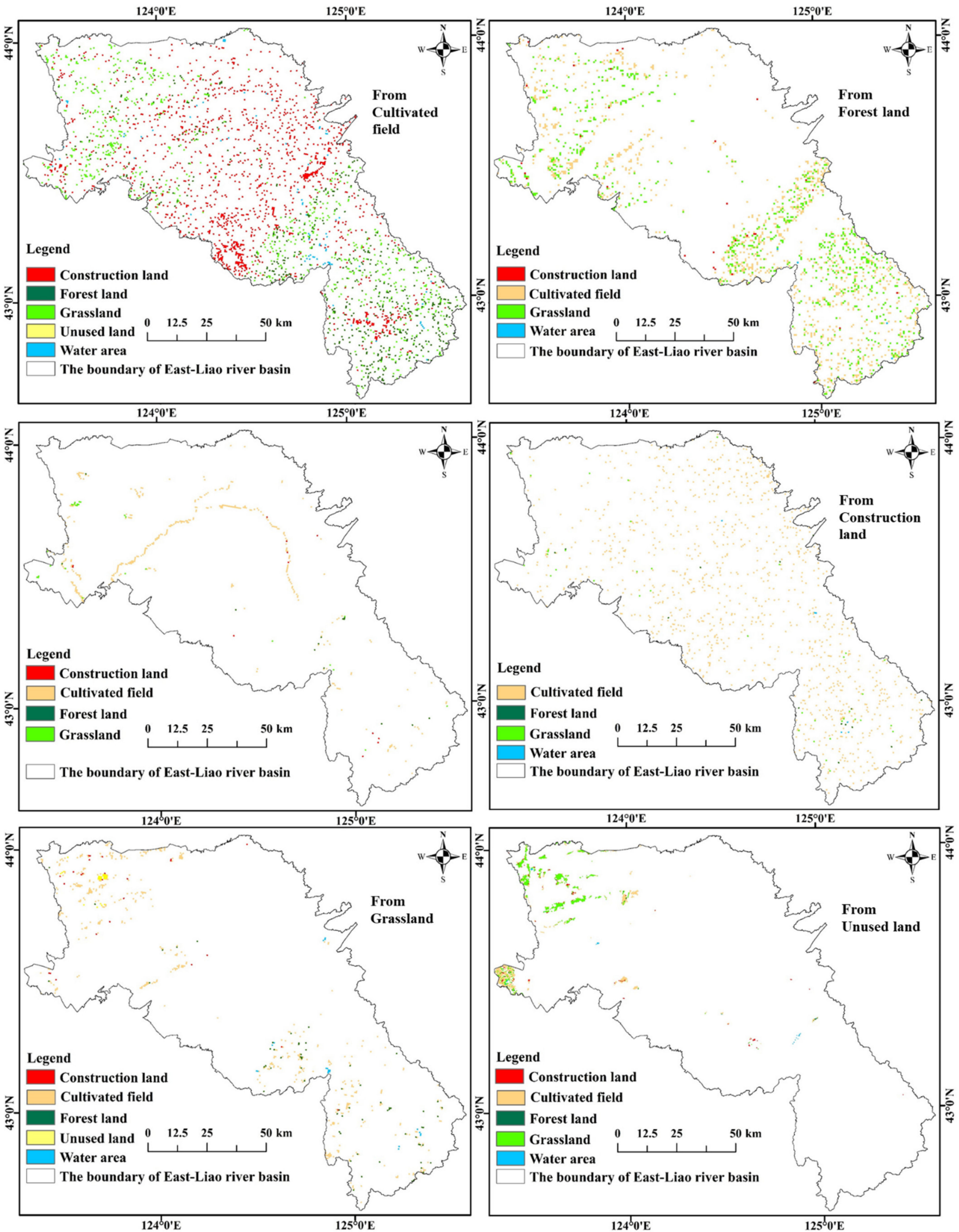

Figure 5. The transfer of land use types from 2000 to $2020\left(\mathrm{~km}^{2}\right)$. 


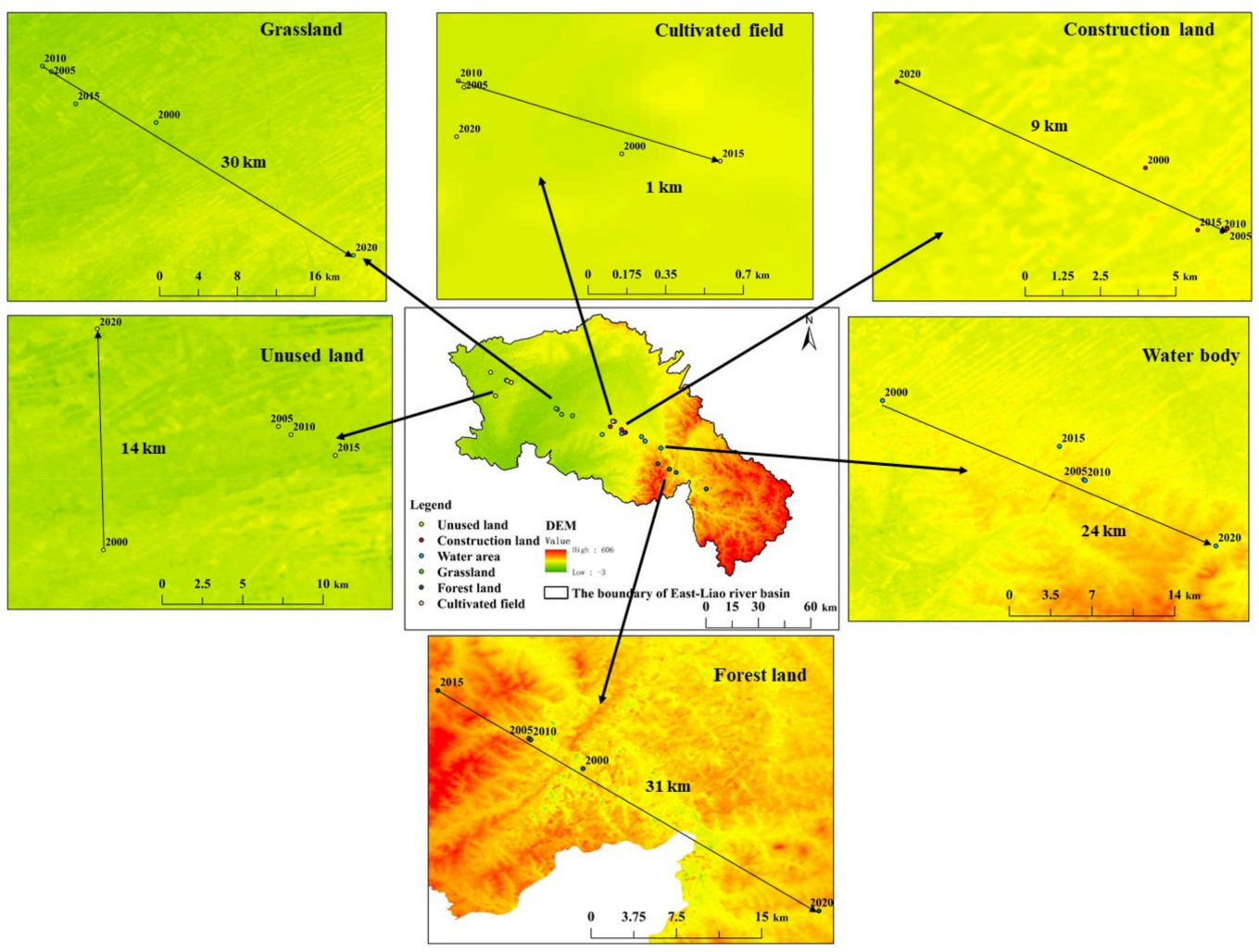

Figure 6. The shift of the center of gravity of land use types from 2000 to 2020 (km).

\subsection{Water Quality Changes}

Water quality grade data of 7 sections were obtained and are shown in Figure 7 in the study area. The water quality grades of monitoring points (1), (2), and (3) were relatively stable, (7) was becoming deteriorated in 2020, and (4), and (6) were improving since 2010 . By 2020, the water body in Area I (monitoring points (1) and (2) was applied to the first-grade protection areas for centralized drinking water and surface water. The water body in Area I (monitoring point (3) and Area II (monitoring points (4), and (6)) can be used in a general industrial water body. However, the water quality of Area III (monitoring point (7) has deteriorated to grade 5. According to Environmental Quality Standards for Surface Water (GB 3838-2002) released by the Ministry of Ecological Environment of China, the water quality grade 5 applied to agricultural water.

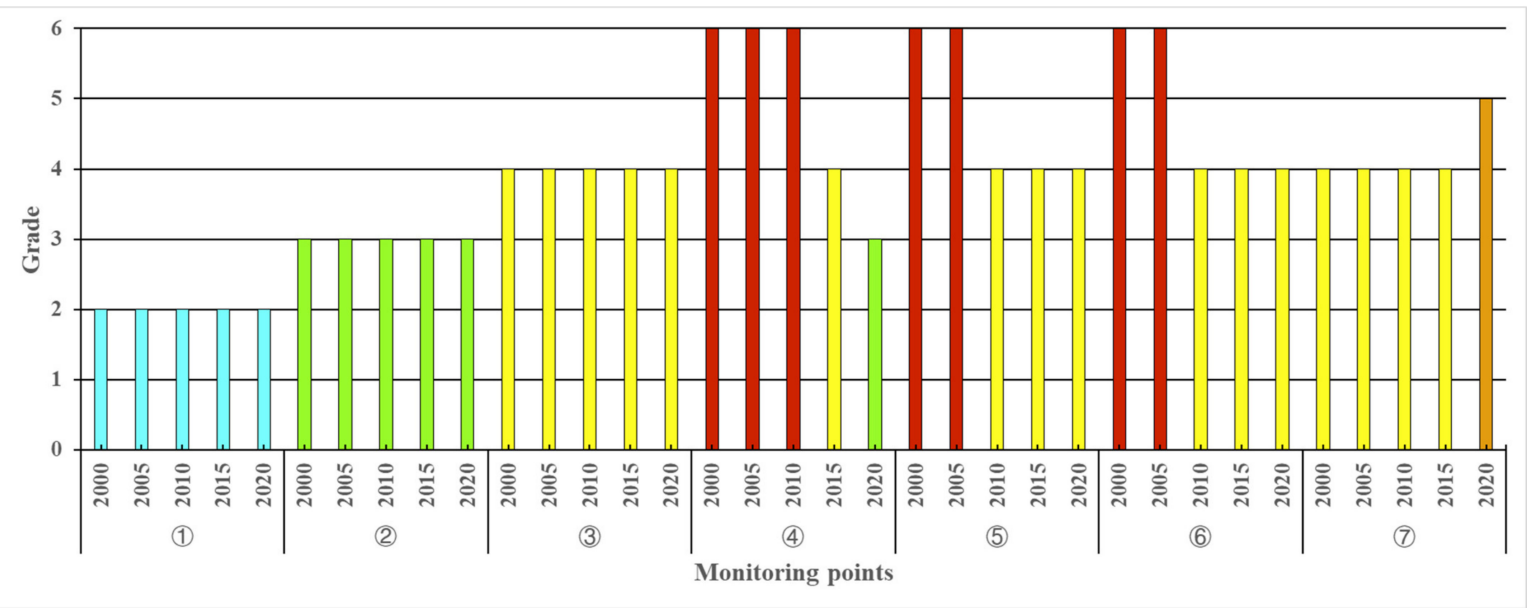

Figure 7. Water quality in the study area from 2000 to 2020. Note: Grades 1-6 indicate water quality I-V, and inferior V. The higher the value, the worse the river water quality grade. 


\subsection{The Impact of Land Use Change on the East-Liao River Basin}

3.3.1. The Land Use Dynamic Degree

A single land use dynamic index $(K)$ could accurately describe the spatial and temporal evolution process and land use intensity. The value $K$ can be calculated by Equation (5) in Table 1. Table 3 shows that grassland's dynamic degrees and unused land are the highest in different study periods and areas.

Table 3. The dynamic degree of single land use in the East-Liao River Basin (\%).

\begin{tabular}{|c|c|c|c|c|c|c|c|c|c|c|c|c|c|}
\hline \multirow{2}{*}{ Period } & \multirow{2}{*}{ Area } & \multicolumn{2}{|c|}{ Cultivated Field } & \multicolumn{2}{|c|}{ Forest Land } & \multicolumn{2}{|c|}{ Grassland } & \multicolumn{2}{|c|}{ Water Body } & \multicolumn{2}{|c|}{ Construction Land } & \multicolumn{2}{|c|}{ Unused Land } \\
\hline & & $K$ & $C$ & $K$ & $C$ & $K$ & C & K & $C$ & K & $C$ & $K$ & C \\
\hline \multirow{3}{*}{$\begin{array}{l}2000- \\
2005\end{array}$} & I & -0.70 & 50.16 & 0.99 & 27.66 & -8.09 & 10.35 & 3.07 & 1.82 & 3.13 & 10.01 & 2.63 & $0 \mathrm{~b}$ \\
\hline & II & -0.48 & 53.08 & 1.33 & 21.06 & -5.74 & 6.84 & 1.94 & 3.43 & 1.85 & 15.32 & 10.19 & $0.28 \mathrm{~b}$ \\
\hline & III & -0.35 & 48.65 & 1.80 & 18.53 & -4.21 & 9.61 & -1.04 & 4.96 & 1.39 & 14.1 & 1.87 & $4.15 \mathrm{a}$ \\
\hline \multirow{3}{*}{$\begin{array}{l}2005- \\
2010\end{array}$} & I & -0.01 & 47.82 & 0.01 & 34.64 & -0.09 & 3.07 & 0.00 & 1.6 & 0.05 & 12.77 & -0.38 & $0.11 \mathrm{~b}$ \\
\hline & II & 0.00 & 48.26 & -0.06 & 27.02 & 0.07 & 2.28 & 0.08 & 2.19 & 0.10 & 19.94 & 1.05 & $0.31 \mathrm{~b}$ \\
\hline & III & 0.00 & 47.08 & -0.06 & 26.52 & 0.28 & 3.39 & 0.07 & 1.99 & 0.12 & 18.29 & -0.35 & $2.73 \mathrm{a}$ \\
\hline \multirow{3}{*}{$\begin{array}{l}2010- \\
2015\end{array}$} & I & 0.19 & 44.36 & -0.07 & 31.89 & 0.05 & 2.65 & -3.47 & 4.6 & -0.40 & 16.42 & 39.20 & $0.09 \mathrm{~b}$ \\
\hline & II & -0.10 & 50.75 & 0.12 & 24.39 & -0.86 & 2.39 & 0.15 & 3.39 & 0.51 & 18.51 & 5.63 & $0.57 \mathrm{~b}$ \\
\hline & III & -0.30 & 54.74 & 1.35 & 23.01 & -1.95 & 4.49 & 0.01 & 2.55 & 0.49 & 13.28 & 0.58 & $1.93 \mathrm{a}$ \\
\hline \multirow{3}{*}{$\begin{array}{l}2015- \\
2020\end{array}$} & I & 1.74 & 31.04 & -4.10 & 46.73 & 79.79 & 3.92 & 0.80 & 1.53 & -6.56 & 16.25 & -16.67 & $0.52 \mathrm{~b}$ \\
\hline & II & 0.73 & 33.63 & -5.96 & 39.83 & 90.76 & 3.18 & -3.78 & 4.89 & -0.29 & 17.58 & -16.67 & $0.89 \mathrm{~b}$ \\
\hline & III & 1.08 & 46.26 & -8.17 & 21.61 & 54.65 & 3.19 & -4.22 & 4.64 & 0.65 & 19.75 & -15.13 & $4.56 \mathrm{a}$ \\
\hline \multicolumn{2}{|c|}{ Mean \pm SD } & ns & $\begin{array}{c}46.32 \pm \\
7.14 \mathrm{a}\end{array}$ & ns & $\begin{array}{c}28.57 \pm \\
8.34 \mathrm{~b}\end{array}$ & ns & $\begin{array}{l}4.61 \pm \\
2.79 \mathrm{~d}\end{array}$ & ns & $\begin{array}{l}3.13 \pm \\
1.35 \mathrm{~d}\end{array}$ & ns & $\begin{array}{c}16.02 \pm \\
3.04 \mathrm{c}\end{array}$ & ns & $\begin{array}{l}1.35 \pm \\
1.63 \mathrm{~d}\end{array}$ \\
\hline
\end{tabular}

Note: Different lowercase letters indicate significant differences $(p<0.05)$, the same below. $K$ refers to the value of a single dynamic degree.

$C$ refers to the value of land use significant. $\mathrm{SD}=$ standard deviation.

\subsubsection{The Important Dynamic Index of Land Use Change}

The larger the land use change value change important index $\left(C_{i}\right)$, the more dominant the land change type $i$, calculated by Equation (6) in Table 1. As shown by $C$ in Table 3, an analysis of variance conducted in different areas found that only the important value of unused land in different areas is meaningful $(p<0.05)$. The variance analysis between land use types found a significant relationship between different land use types $(p<0.05)$.

The $C_{i}$ values were sorted in descending order from largest to smallest and it was statistically found that the cultivated field was dominant in the three areas from 2000 to 2015. In 2015-2020, Area I and Area II were dominated by forest land, and Area III was still dominated by cultivated field.

\subsubsection{The Information Entropy of Land Use Structure Change}

The information entropy values of land use structure could describe a regional land use type. The information entropy value of land use in different areas is calculated by Equation (7) in Table 1. Table 4 shows that the information entropy value of land use is ranked as Area I > Area III > Area II, all of which reach a significant level $(p<0.05)$. The entropy value of land use in Area I showed an increase-decrease-increase trend. However, the entropy value of land use in Areas II and III showed a trend of first increasing and then decreasing. In Area II, the information entropy change of land use in different periods accords the Quadratic polynomial model: $\hat{y}=0.832+0.044 x-0.006 x^{2}$. 
Table 4. Dynamic changes of land use information entropy index in the East-Liao River Basin (\%).

\begin{tabular}{cccc}
\hline \multirow{2}{*}{ Year } & \multicolumn{3}{c}{ Value of Land Use Information Entropy } \\
\cline { 2 - 4 } & I & II & III \\
\hline 2000 & 1.03 & 0.87 & 0.93 \\
2005 & 1.04 & 0.90 & 0.95 \\
2010 & 1.04 & 0.91 & 0.95 \\
2015 & 1.03 & 0.92 & 0.97 \\
2020 & 1.07 & 0.91 & 0.89 \\
Mean \pm SD & $1.0420 \pm 0.0164 \mathrm{a}$ & $0.9020 \pm 0.0192 \mathrm{c}$ & $0.9607 \pm 0.0650 \mathrm{~b}$ \\
\hline
\end{tabular}

\subsection{Grey Correlation Analysis of Water Quality and Land Use Change Index}

Using Equations (8) and (9), the grey correlation analysis of water quality grade was calculated using the dynamic attitude, importance, and information entropy index of land use. When the reliability of the model is verified, not only the grey correlation degree $R\left(x_{0}\right.$, $\left.x_{1}\right)>R\left(x_{0}, x_{2}\right)$ was obtained, but also the difference was noticeable. The calculation results (Table 5) show that the water quality at points (1) and (2) has a strong correlation with the dynamic degree of forest land and the importance of the water body. There was a strong correlation between water quality and forest land importance at point (3). At point (4), there was a strong correlation between water quality and dynamic grassland degree. There was a strong correlation between the water quality of point (4) and the dynamic degree of forest land and the importance of construction land. There was a strong correlation between the water quality of point (6) and the importance of the water body. The water quality of point (6) had the strongest correlation with the importance of the cultivated fields and construction land.

Table 5 shows a strong correlation between land use change index and water quality. Therefore, water quality can be improved by controlling changes in land use types.

Table 5. Correlation and ranking between water quality and land use change index.

\begin{tabular}{|c|c|c|c|c|c|c|c|c|c|c|}
\hline \multirow{2}{*}{$\begin{array}{l}\text { Area } \\
\text { Type }\end{array}$} & \multirow{2}{*}{$\begin{array}{c}\mathbf{R i} \\
\text { Indicator }\end{array}$} & \multicolumn{3}{|c|}{$\mathbf{I}$} & \multicolumn{2}{|c|}{ II } & \multicolumn{2}{|c|}{ III } & \multirow{2}{*}{$\begin{array}{l}\text { Correlation } \\
\text { Degree }\end{array}$} & \multirow{2}{*}{ Sort } \\
\hline & & (1) & (2) & (3) & (4) & (5) & (6) & (7) & & \\
\hline \multirow{7}{*}{$\begin{array}{l}\text { Single } \\
\text { dynamic } \\
\text { degree }\end{array}$} & Cultivated field & 0.86 & 0.86 & 0.94 & 0.87 & 0.90 & 0.93 & 0.95 & 0.90 & 9 \\
\hline & Forest land & 0.97 & 0.97 & 0.93 & 0.97 & 1.00 & 0.99 & 0.97 & 0.97 & 3 \\
\hline & Grassland & 0.94 & 0.94 & 0.97 & 0.98 & 0.98 & 0.94 & 0.96 & 0.96 & 7 \\
\hline & Water body & 0.91 & 0.91 & 0.83 & 0.94 & 0.98 & 0.81 & 0.80 & 0.88 & 11 \\
\hline & Construction land & 0.33 & 0.33 & 0.35 & 0.42 & 0.43 & 0.38 & 0.39 & 0.38 & 13 \\
\hline & Unused land & 0.80 & 0.80 & 0.87 & 0.85 & 0.87 & 0.86 & 0.87 & 0.84 & 12 \\
\hline & Cultivated field & 0.95 & 0.95 & 0.96 & 0.96 & 0.99 & 0.99 & 1.00 & 0.97 & 4 \\
\hline \multirow{5}{*}{$\begin{array}{l}\text { Land use } \\
\text { change } \\
\text { important }\end{array}$} & Forest land & 0.92 & 0.92 & 0.99 & 0.95 & 0.98 & 0.95 & 0.96 & 0.95 & 8 \\
\hline & Grassland & 0.93 & 0.93 & 0.97 & 0.93 & 0.96 & 0.99 & 0.99 & 0.96 & 6 \\
\hline & Water body & 0.97 & 0.97 & 0.94 & 0.97 & 0.99 & 1.00 & 0.98 & 0.97 & 1 \\
\hline & Construction land & 0.95 & 0.95 & 0.95 & 0.97 & 1.00 & 0.99 & 1.00 & 0.97 & 2 \\
\hline & Unused land & 0.95 & 0.95 & 0.87 & 0.89 & 0.92 & 0.82 & 0.81 & 0.89 & 10 \\
\hline \multicolumn{2}{|c|}{ The information entropy of land use structure } & 0.93 & 0.93 & 0.97 & 0.95 & 0.98 & 0.98 & 0.99 & 0.96 & 5 \\
\hline
\end{tabular}

\section{Discussion}

(1) Several studies have shown that land use changes significantly impact global environmental changes [43]. Most of the studies focus on the cultivated field and forest land. However, grassland has essential ecological functions in preventing wind, fixing sand, conserving water, soil, and maintaining biodiversity [44-46].

From 2000 to 2020, the cultivated land was the primary land use in the East-Liao River Basin. Grassland only accounted for $3.87 \%$ of the cultivated field. However, due to the change in land use, the grassland area decreased from 2000 to 2015. By 2015, the grassland area decreased from 304.56 to $204.38 \mathrm{~km}^{2}$. The central area of grassland area change appeared in the ecotone between agriculture and animal husbandry. Table 6 shows the percentage of grassland transferred to other land use types from 2000 to 2020. Human beings' over-utilization may cause this situation and increase population [47,48], human intervention and interference in climate warming/drying, and annual precipitation [49]. 
It makes the grassland area change closely related to increased or decreased cultivated fields [50]. Other studies also pointed out that the grassland area decreased in these periods [51-53].

However, the grassland area has increased substantially from 2015 to 2020 . The grassland area during 2020 was equivalent to more than twice the grassland area in 2000. This situation can be explained by the grassland transition matrix, as shown in Figure 8 . However, due to cultivated fields, forest land, and construction land to grassland, grassland areas increased rapidly between 2015 and 2020. Among them, cultivated field transferred to grassland accounted for $73 \%$. Therefore, the rapid growth of the grassland area in 20152020 may be caused by returning cultivated fields to the grassland, as proposed in China. Driven by the policy of returning the cultivated fields to grassland, the grassland area has been restored. The ecological function of grassland has been further improved. This phenomenon reminds us to rationalize artificial governance and policy adjustments [54].

Table 6. Types and weights of land use transferred from grassland from 2000 to 2020.

\begin{tabular}{cccc}
\hline Year & Weight & Type \\
\hline & & $25 \%$ & Cultivated field \\
& & $19 \%$ & Unused land \\
& & $15 \%$ & Forest land \\
& & Construction land & Water body \\
& $63 \%$ & $2 \%$ & Cultivated field \\
$2005-2010$ & & $2 \%$ & Cultivated field \\
& & $8 \%$ & Forest land \\
& & $13 \%$ & Unused land \\
& & $4 \%$ & Construction land \\
& $22 \%$ & $3 \%$ & Water body \\
& & $1 \%$ & Cultivated field \\
& & $1 \%$ & Construction land \\
& & $77 \%$ & Forest land
\end{tabular}

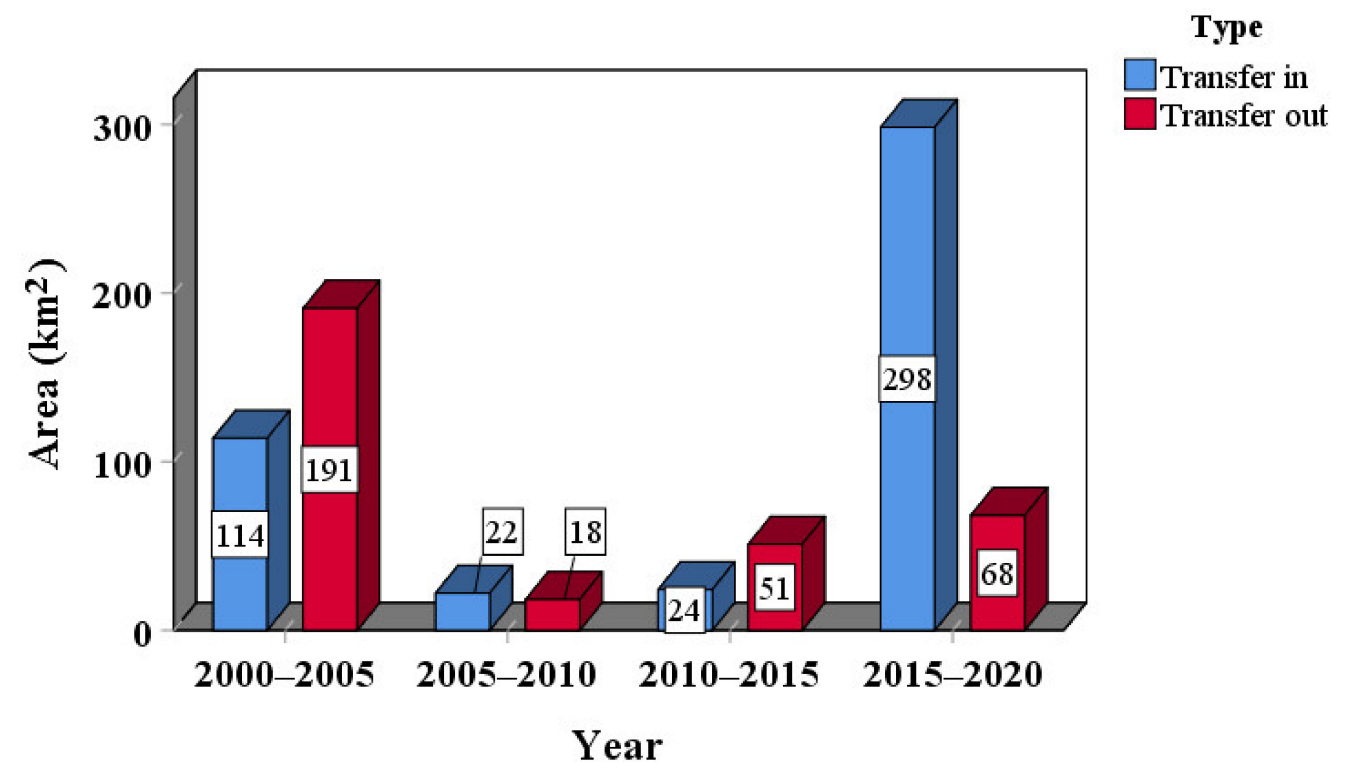

Figure 8. Grassland transfer in/out area from 2000 to $2020\left(\mathrm{~km}^{2}\right)$.

(2) After the grassland was converted into the cultivated field, non-point source pollution appeared due to excessive artificial fertilization and over-utilization of the cultivated fields $[55,56]$. Non-point source pollution increases the pollutants, and surface runoff 
brings pollutants to the surface of the water body [57,58], which has a specific impact on river basin water pollution. Supposing that this impact exceeds the self-purification degree of rivers, it will endanger the river ecosystem and lead to a series of ecological water problems [21]. Some studies also provided evidence of the close relationship between land use types and water quality characteristics in other basins $[59,60]$. Compared with other land use types, the water body of the East-Liao River Basin is relatively small. The East-Liao River Basin flows through Liaoyuan city, Siping city, and Gongzhuling city. The shortage of water resources also increases the difficulty of water quality control.

The river water quality is affected by land use change. The spatial water quality (Figure 7) shows that the water quality in Area III is the worst, and the water quality grade in Area I is good. Area I covers a large area of forest and grass, and human activities have little impact on Area I. The water quality grade in Area II is getting worse. In Area III, the water quality is gradually deteriorating and can only be used for agricultural irrigation. According to the local policies, the water body in Area I is suitable for the local water source protection area in 2020.

(3) The results of land use information entropy show that the information entropy value of Area I is higher than that of Areas II and III. This phenomenon can be explained by the small difference in land use types and the balanced land use structure in Area I (mainly Liaoyuan City). However, there is a huge difference in land use types between Areas II and III (mainly Siping City and Gongzhuling City). The land use structure is chaotic. The East-Liao River Basin is an important water source protection area in Northeast China. Table 7 shows the national spatial planning of the study area (2018-2035). Among them, Liaoyuan City has a balanced land structure and abundant forest land resources. The river water entrance in the East-Liao River Basin is in Liaoyuan City. Once its water quality is polluted, it will affect the water body of other areas. Therefore, government departments should pay attention to the impact of local land use change on water quality.

Table 7. Opinion for ecological conservation importance grades in the city of East-Liao River Basin $\left(\mathrm{km}^{2}\right)$.

\begin{tabular}{cccc}
\hline Area & Extreme Importance & Importance & Unimportance \\
\hline Siping & 1521.68 & 4196.59 & 4523.45 \\
Liaoyuan & 1023.57 & 914.62 & 678.57 \\
Gongzhuling & 119.17 & 809.04 & 3212.4 \\
\hline
\end{tabular}

\section{Conclusions}

In this study, the land use change index and its relationship to the water quality of the East-Liao River Basin in Jilin Province were studied since 2000. The land use change index of the study area was analyzed to reveal the land use change in different areas. Then, the grey correlation degree between these indexes and water quality parameters was established. The following conclusions were drawn:

(1) The area of cultivated land, grassland, and construction land expanded. The area of forest land, water bodies, and unused land reduced during 2000-2020.

(2) The transfer rate is cultivated field $>$ forest land $>$ construction land $>$ grassland $>$ unused land $>$ water body.

(3) The migration range can be ranked as forest land $>$ grassland $>$ water body $>$ unused land $>$ construction land $>$ cultivated field.

(4) Among the three areas, the water quality grade is as follows: Area I > Area II > Area III.

(5) The entropy value of land use information is expressed as Area I > Area III > Area II.

(6) Land use change index has a strong correlation with water quality, and can improve and manage water quality by changing the area of land use types.There was a strong correlation between land use change index and water quality, and water quality can be improved and managed by changing the area of land use types. 


\section{Policy and Management Recommendations}

Given the water quality problems caused by the land use change in the East-Liao River Basin, three suggestions are put forward: (1) establishing ecological protection zones or ecological function areas in Area I, (2) constructing artificial lawns or plantations in the river courses around the water body in the middle reaches of the river to intercept pollutants from non-point source pollution in the area, and (3) carrying out scientific and reasonable cultivation in the lower reaches of rivers to reduce non-point source pollution generated by cultivation.

Author Contributions: Conceptualization, M.Z. and X.L.; methodology, A.H., Z.T. and D.R.; software, G.R. and J.Z.; writing-original draft preparation, M.Z. and X.L. All authors have read and agreed to the published version of the manuscript.

Funding: This research was funded by the Major Scientific and Technological Program of Jilin Province (Grant No.20200503002SF) and the Science and Technology Development Planning of Jilin Province (Grant No.20190303081SF).

Institutional Review Board Statement: Not applicable.

Informed Consent Statement: Not applicable.

Data Availability Statement: The land use data, meteorological data and image data in this paper can be obtained from https://www.resdc.cn/, http://data.cma.cn/ and http://www.gscloud.cn/, respectively.

Acknowledgments: The authors are thankful to the anonymous reviewers for their useful suggestions.

Conflicts of Interest: The authors declare no conflict of interest.

\section{References}

1. Min, K.C. Land use classification and land use change analysis using satellite images in Lombok Island, Indonesia. For. Sci. Technol. 2016, 12, 183-191. [CrossRef]

2. Zhang, C.; Shoemaker, C.A.; Woodbury, J.D.; Cao, M.; Zhu, X. Impact of human activities on stream flow in the Biliu River basin, China. Hydrol. Process. 2013, 27, 2509-2523. [CrossRef]

3. Lambin, E.F.; Geist, H.J.; Lepers, E. Dynamics of land-use and land-cover change in tropical regions. Annu. Rev. Environ. Resour. 2003, 28, 205-241. [CrossRef]

4. Ramankutty, N.; Foley, J.A. Estimating historical changes in global land cover: Croplands from 1700 to 1992. Glob. Biogeochem. Cycles 1999, 13, 997-1027. [CrossRef]

5. Chen, X.; Wang, Z. Land Use Change and Its Impact on Water Resources in East River Basin, South China. J. Beijing Norm. University. Nat. Sci. 2010, 46, 311-316.

6. Zhang, T.; Zhang, X.; Xia, D.; Liu, Y. An Analysis of Land Use Change Dynamics and Its Impacts on Hydrological Processes in the Jialing River Basin. Water 2014, 6, 3758-3782. [CrossRef]

7. Fernandes, M.R.; Aguiar, F.C.; Martins, M.J.; Rivaes, R.; Ferreira, M.T. Long-term human-generated alterations of Tagus River: Effects of hydrological regulation and land-use changes in distinct river zones. Catena 2020, 188. [CrossRef]

8. Zheng, H.; Yuan, Y.; Feng, W.; Shi, P. Model research on impact of land-use change on surface runoff depth: A case study on Shenzhen Region. J. Nat. Disasters 2005, 14, 77-82.

9. Berihun, M.L.; Tsunekawa, A.; Haregeweyn, N.; Meshesha, D.T.; Adgo, E.; Tsubo, M.; Masunaga, T.; Fenta, A.A.; Sultan, D.; Yibeltal, M.; et al. Hydrological responses to land use/land cover change and climate variability in contrasting agro-ecological environments of the Upper Blue Nile basin, Ethiopia. Sci. Total Environ. 2019, 689, 347-365. [CrossRef]

10. Zhang, H.; Wang, B.; Liu, D.L.; Zhang, M.; Leslie, L.M.; Yu, Q. Using an improved SWAT model to simulate hydrological responses to land use change: A case study of a catchment in tropical Australia. J. Hydrol. 2020, 585. [CrossRef]

11. Shenfa, H.; Min, W.; Yue, C.H.E.; Kai, Y. Effect of Land Use on Water Quality in Waterhead Region in River Network Plain-A Case Study of the Upper Huangpu River. J. Ecol. Rural Environ. 2006, 22, 14-19.

12. Xu, Q.; Wang, P.; Shu, W.; Zhang, H.; Ding, M. Investigation of the impacts of land use structure and spatial pattern on water quality in the Yuan River. Acta Sci. Circumstantiae 2020, 40, 2611-2620.

13. Gossweiler, B.; Wesstrom, I.; Messing, I.; Villazon, M.; Joel, A. Impact of Land Use Change on Non-Point Source Pollution in a Semi-Arid Catchment under Rapid Urbanisation in Bolivia. Water 2021, 13, 410. [CrossRef]

14. Alijani, Z.; Hosseinali, F.; Biswas, A. Spatio-temporal evolution of agricultural land use change drivers: A case study from Chalous region, Iran. J. Environ. Manag. 2020, 262. [CrossRef] [PubMed] 
15. Hashim, A.M.; Elkelish, A.; Alhaithloul, H.A.; El-hadidy, S.M.; Farouk, H. Environmental monitoring and prediction of land use and land cover spatio-temporal changes: A case study from El-Omayed Biosphere Reserve, Egypt. Environ. Sci. Pollut. Res. 2020. [CrossRef]

16. Ustaoglu, E.; Aydinoglu, A.C. Regional variations of land-use development and land-use/cover change dynamics: A case study of Turkey. Remote Sens. 2019, 11, 885. [CrossRef]

17. Chen, Q.; Chen, H.; Zhang, J.; Hou, Y.; Shen, M.; Chen, J.; Xu, C. Impacts of climate change and LULC change on runoff in the Jinsha River Basin. J. Geogr. Sci. 2020, 30, 85-102. [CrossRef]

18. Rizzo, R.; Garcia, A.S.; Vilela, V.M.d.F.N.; Ballester, M.V.R.; Neill, C.; Victoria, D.C.; Da Rocha, H.R.; Coe, M.T. Land use changes in Southeastern Amazon and trends in rainfall and water yield of the Xingu River during 1976-2015. Clim. Chang. 2020, 162, 1419-1436. [CrossRef]

19. Wan, L.; Liu, H.; Gong, H.; Ren, Y. Effects of climate and land use changes on vegetation dynamics in the Yangtze River Delta, China based on abrupt change analysis. Sustainability 2020, 12, 1955. [CrossRef]

20. Chen, D.; Elhadj, A.; Xu, H.; Xu, X.; Qiao, Z. A study on the relationship between land use change and water quality of the Mitidja watershed in Algeria based on GIS and RS. Sustainability 2020, 12, 3510. [CrossRef]

21. Batbayar, G.; Pfeiffer, M.; Kappas, M.; Karthe, D. Development and application of GIS-based assessment of land-use impacts on water quality: A case study of the Kharaa River Basin. Ambio 2019, 48, 1154-1168. [CrossRef]

22. Rodrigues, V.; Estrany, J.; Ranzini, M.; De Cicco, V.; Tarjuelo Martin-Benito, J.M.; Hedo, J.; Lucas-Borja, M.E. Effects of land use and seasonality on stream water quality in a small tropical catchment: The headwater of Corrego Agua Limpa, Sao Paulo (Brazil). Sci. Total Environ. 2018, 622, 1553-1561. [CrossRef] [PubMed]

23. Zhang, J.; Yu, X. Analysis of land use change and its influence on runoff in the Puhe River Basin. Environ. Sci. Pollut. Res. 2020. [CrossRef]

24. Ervinia, A.; Huang, J.; Huang, Y.; Lin, J. Coupled effects of climate variability and land use pattern on surface water quality: An elasticity perspective and watershed health indicators. Sci. Total Environ. 2019, 693, 133592. [CrossRef] [PubMed]

25. Huang, Y.; Huang, J. Coupled effects of land use pattern and hydrological regime on composition and diversity of riverine eukaryotic community in a coastal watershed of Southeast China. Sci. Total Environ. 2019, 660, 787-798. [CrossRef]

26. Chen, L.; Chang, J.; Wang, Y.; Zhu, Y. Assessing runoff sensitivities to precipitation and temperature changes under global climate-change scenarios. Hydrol. Res. 2019, 50, 24-42. [CrossRef]

27. Li, Y.; Chang, J.; Luo, L.; Wang, Y.; Guo, A.; Ma, F.; Fan, J. Spatiotemporal impacts of land use land cover changes on hydrology from the mechanism perspective using SWAT model with time-varying parameters. Hydrol. Res. 2019, 50, 244-261. [CrossRef]

28. Yang, P.; Xia, J.; Zhan, C.; Chen, X.; Qiao, Y.; Chen, J. Separating the impacts of climate change and human activities on actual evapotranspiration in Aksu River Basin ecosystems, Northwest China. Hydrol. Res. 2018, 49, 1740-1752. [CrossRef]

29. Zhang, Y.; Tang, J.; Li, Z.; Bai, Y.; Pan, Y.; Wang, X. Characteristics of agricultural non-point source pollution in Zhaosutai Basin of Jilin Province. Environ. Pollut. Control 2015, 37, 29-34, +40.

30. Al-Shaibah, B.; Liu, X.; Zhang, J.; Tong, Z.; Zhang, M.; El-Zeiny, A.; Faichia, C.; Hussain, M.; Tayyab, M. Modeling Water Quality Parameters Using Landsat Multispectral Images: A Case Study of Erlong Lake, Northeast China. Remote Sens. 2021, 13, 1603. [CrossRef]

31. Sun, L.; Lu, W.; Yang, Q.; Hou, Z.; Si, C. Effect of future land use caused change on the non-point source pollution in Dongliao River weatershed. China Environ. Sci. 2013, 33, 1459-1467.

32. Resources and Environmental Science Data Center. Land Use Data. 2020. Available online: https://www.resdc.cn/ (accessed on 10 April 2019).

33. Cloud, G.D. Digital Elevation Model. 2020. Available online: http://www.gscloud.cn/ (accessed on 15 October 2019).

34. Liu, R.; Zhu, D. Methods for detecting land use changes based on the land use transition matrix. Resour. Sci. 2010, 32, 1544-1550.

35. Lian, X. Analysis on the space evolvement track of population gravity center, employment gravity center and economic gravity center. Popul. J. 2007, 3, 23-28.

36. Wang, G.; Wang, S.; Chen, Z. Land-use/land-cover changes in the Yellow River basin. J. Tsinghua Univ. (Sci. Technol.) 2004, 44, 1218-1222.

37. Liu, F.; Yang, G.; Han, X.; Jia, G.; Wang, N. Spatial-temporal evolution of land use and spatial autocorrelation analysis in Horqin Sandy Land-A case study of Naiman banner. J. Northwest For. Univ. 2020, 35, 148-157.

38. Luo, Y.; Yang, S.; Liu, X.; Liu, C.; Song, W.; Dong, G.; Zhao, H.; Lou, H. Land use change in the reach from Hekouzhen to Tongguan of the Yellow River during 1998-2010. Acta Geogr. Sin. 2014, 69, 42-53.

39. Wang, Z. Strategical thinking of protecting grassland ecology in China. Grassl. China 2005, 27, 1-9.

40. Zhang, S.; Zhang, G. Comparison between computation models of grey interconnet degree and analysis on their shortages. Syst. Eng. 1996, 3, 45-49.

41. Liu, S.; Lin, Y. Grey System Theory and Application; Springer: Berlin/Heidelberg, Germany, 2011.

42. Lu, Z.; Fan, X.; Li, G.; Yue, C. A modeling credibility validation algorithm based on grey relational analysis. Comput. Appl. Softw. 2013, 30, 252-254.

43. Vanwalleghem, T.; Gomez, J.A.; Infante Amate, J.; Gonzalez de Molina, M.; Vanderlinden, K.; Guzman, G.; Laguna, A.; Giraldez, J.V. Impact of historical land use and soil management change on soil erosion and agricultural sustainability during the Anthropocene. Anthropocene 2017, 17, 13-29. [CrossRef] 
44. Wang, D.; Wang, L.; Xin, X.; Li, L.; Tang, H. Systematic Restoration for Degraded Grasslands: Concept, Mechanisms and Approaches. Sci. Agric. Sin. 2020, 53, 2532-2540.

45. White, R.P.; Murray, S.; Rohweder, M. Pilot Analysis of Global Ecosystems: Grassland Ecosystems. World Resour. Inst. 2000, 4, 275.

46. Lou, P.; Fu, B.; Liu, H.; Gao, E.; Fan, D.; Tang, T.; Lin, X. Dynamic evaluation of grassland ecosystem services in Xilingol League. Acta Ecol. Sin. 2019, 39, 3837-3849.

47. Zou, Y.; Zhang, Z.; Zhao, X.; Liu, B.; Tan, W. Analysis of grassland resource dynamics in China's Arid Region supported by RS and GIS. Res. Environ. Sci. 2003, 16, 19-22, +26.

48. Zou, Y.; Zhang, Z.; Zhou, Q.; Tan, W. Analysis of grassland dynamic in China based on RS and GIS. Resour. Sci. $2002,24,42-47$.

49. Pulido, M.; Schnabel, S.; Lavado Contador, J.F.; Lozano-Parra, J.; Gonzalez, F. The impact of heavy grazing on soil quality and pasture production in rangelands of SW spain. Land Degrad. Dev. 2018, 29, 219-230. [CrossRef]

50. Li, X.; Wei, Y.; Zhang, C. Variation of grassland area and its cause in Inner Mongolia A case study on Duolun County of Xilin Gol League. Pratacult. Sci. 2012, 29, 19-24.

51. Wang, J.; Zhang, W.; Zhang, Z. Impacts of land-use changes on soil erosion in water-wind crisscross erosion region of China. Remote Sens. 2019, 11, 1732. [CrossRef]

52. Wimberly, M.C.; Janssen, L.L.; Hennessy, D.A.; Luri, M.; Chowdhury, N.M.; Feng, H. Cropland expansion and grassland loss in the eastern Dakotas: New insights from a farm-level survey. Land Use Policy 2017, 63, 160-173. [CrossRef]

53. Liu, J.; Kuang, W.; Zhang, Z.; Xu, X.; Qin, Y.; Ning, J.; Zhou, W.; Zhang, S.; Li, R.; Yan, C.; et al. Spatiotemporal characteristics, patterns, and causes of land-use changes in China since the late 1980s. J. Geogr. Sci. 2014, 24, 195-210. [CrossRef]

54. Szewranski, S.; Chruscinski, J.; Van Hoof, J.; Kazak, J.K.; Swiader, M.; Tokarczyk-Dorociak, K.; Zmuda, R. A location intelligence system for the assessment of Pluvial flooding risk and the identification of storm water pollutant sources from roads in Suburbanized areas. Water 2018, 10, 746. [CrossRef]

55. Lijuan, L.I.; Dejuan, J.; Jiuyi, L.I.; Liqiao, L.; Li, Z. Advances in hydrological response to land use/land cover change. J. Nat. Resour. 2007, 22, 211-224.

56. Miller, J.D.; Kim, H.; Kjeldsen, T.R.; Packman, J.; Grebby, S.; Dearden, R. Assessing the impact of urbanization on storm runoff in a pen-urban catchment using historical change in impervious cover. J. Hydrol. 2014, 515, 59-70. [CrossRef]

57. Jacobson, C.R. Identification and quantification of the hydrological impacts of imperviousness in urban catchments: A review. J. Environ. Manag. 2011, 92, 1438-1448. [CrossRef]

58. Tong, S.T.Y.; Chen, W.L. Modeling the relationship between land use and surface water quality. J. Environ. Manag. 2002, 66, 377-393. [CrossRef] [PubMed]

59. Gburek, W.J.; Folmar, G.J. Flow and chemical contributions to streamflow in an upland watershed: A baseflow survey. J. Hydrol. 1999, 217, 1-18. [CrossRef]

60. Liu, A.J.; Tong, S.T.Y.; Goodrich, J.A. Land use as a mitigation strategy for the water-quality impacts of global warming: A scenario analysis on two watersheds in the Ohio River Basin. Environ. Eng. Policy 1999, 2, 65-76. [CrossRef] 